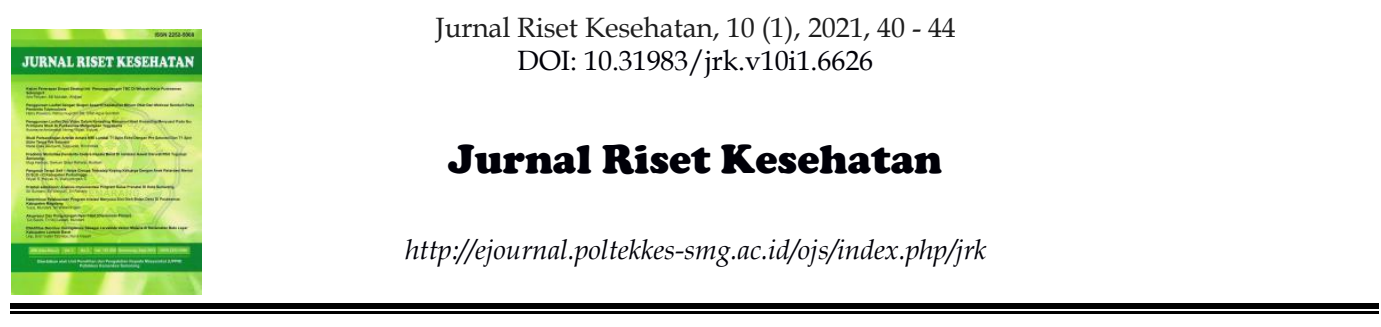

\title{
IDENTIFICATION OF CYCLAMATE ON BRANDED AND UNBRANDED BUBBLE DRINK IN DENPASAR CITY
}

\author{
Ayu Saka Laksmita $\mathrm{W}^{\mathrm{a}^{*}}$; Ni Putu Widayanti ${ }^{\mathrm{b}}$; Desak Putu Risky VA \\ a,b,c Medical Laboratory Technology ; Faculty of Health Sciences ; Universitas Bali Internasional \\ Seroja Gang Jeruk street ; Denpasar 80239; Indonesia
}

\begin{abstract}
Bubble drink is a drink that is on the rise at this time. This drink is liked by many people Bubble drink is a drink that is on the rise at this time. This drink is liked by many people because it has a sweet taste. To create a sweet taste, there are usually 2 kinds, namely natural and artificial sweeteners. Cyclamate is a type of artificial sweetener that is 30 times sweeter than sucrose. The side effects of artificial sweeteners if consumed in excessive amounts can pose a danger to human health. Among other things, it can cause urinary tract cancer and migraines. This study aims to qualitatively identify cyclamate content in bubble drinks circulating in the city of Denpasar. The total number of samples was 30 samples of bubble drinks. This research method is a descriptive study with purposive sampling, the results of the data analysis are presented in tabular form without data processing. Sample identification is done by qualitative test. The test results showed that 20 of the samples of bubble branded drinks and 10 of the samples of unbranded bubble drinks were safe from cyclamate sweetener content.
\end{abstract}

Keywords: bubble drink; artificial sweetener; cyclamate

\section{Introduction}

Cases of misuse of food additives that usually occur are the use of additives that are prohibited for foodstuffs and the use of foodstuffs that exceeds the specified limits. Another reason, producers are trying to meet needs by getting big profits, but low prices through the use of food coloring agents that are used to maintain food conditions to make them attractive (Syarifudin et al., 2017). The more food ingredients will add flavor to the food itself. Food complementary ingredients that are currently favored by the public, because they can increase the taste of food, one of which is a drink containing bubble toppings. To improve the quality of food products so that they can compete in the market, food additives are needed, such as sweeteners, dyes, preservatives, flavor, antioxidants, thickeners and sweeteners (Winarno, 2004). Usually, beverage manufacturers prefer artificial sweeteners to

\footnotetext{
*) Corresponding Author (Ayu Saka Laksmita W)

E-mail: sakalaksmita@gmail.com
}

natural sweeteners. This is due to prices that are more affordable than natural sweeteners (Ramadhani et al., 2018).

One of the Food Additives (BTP) found in beverages is an artificial sweetener, namely cyclamate. Cyclamate is a synthetic sweetener is generally not used in several countries because its degradation products are carcinogenic. However, in Indonesia, the use of cyclamate as an artificial sweetener in food is still allowed. According to the Decree of the Head of BPOM Number HK.00.05.5.1.4547 of 2004, regarding the requirements for the use of artificial sweetener food additives in food products, the limit for using cyclamate is set based on the food category, for the category of food supplements it cannot exceed $1.25 \mathrm{~g} / \mathrm{kg}$, 2018).

The limit of daily cyclamate intake is based on the Regulation of the Minister of Health of the Republic of Indonesia No. 722 / Menkes / Per / IX / 88 in Cahyadi (2008), which is allowed in low-calorie food and drinks for the general public is $3 \mathrm{~g} / \mathrm{kg}$. Usually, for each sweetener, there is an allowable daily consumption value or 
better known as ADI (Allowed Daily Intake). It can be concluded that sweeteners that are licensed and circulating in the market if consumed in sufficient quantities will not cause serious side effects. Artificial sweeteners pose many dangers to human health. Among other things, it can cause urinary tract cancer and migraines. Side effects will appear if the sweetener is consumed in excessive amounts.

A study shows that the use of cyclamate can be dangerous considering its metabolic results, namely, cyclohexanone is carcinogenic, so that secretion through urine can stimulate tumor growth in the bladder of mice (Ramadhani et al., 2018). One of the criteria for the safety of street food sold is that it is safe from nutritional composition and food additives, so the composition of snack foods must be considered (Marlina and Annisa, 2016). Based on the theory presented previously, it is necessary to conduct research to identify artificial sweeteners, namely cyclamate in bubble beverage products that are currently on the rise in the market in Denpasar city.

\section{Method}

This research method is a descriptive study with purposive sampling, the results of the data analysis are presented in tabular form without data processing. The sample selection was taken by purposive sampling, namely the drinks with bubble topping were taken deliberately according to the considerations and needs. Analysis of the artificial dye content in the sample will be carried out in the laboratory so that it can be used to conclude. This research will be conducted with a total of 30 bubble drink circulating in Denpasar City. All samples were collected at each point of the city of Denpasar, namely North Denpasar, East Denpasar, South Denpasar, and West Denpasar.

Tools and Materials are glass tools, water bath, Whatman filter paper, scales, beaker glass, stirring rods, dropper pipettes, volume pipettes, separating funnels, bubble drink samples, aqua dest, cyclamate, $10 \% \mathrm{HCL}, 10 \% \mathrm{BaCl} 2,10 \%$ $\mathrm{NaNO} 2$. This research was conducted at the microbiology laboratory, Faculty of Health Sciences, Bali International University. The sample was weighed $50 \mathrm{mg}$ of the material to be tested and then put into a beaker glass and $50 \mathrm{ml}$ of distilled water was added. After that, it is filtered with Whatman filter paper so that the filtrate is obtained. Then added with $10 \mathrm{ml}$ of $10 \% \mathrm{HCl}$ and $10 \mathrm{ml}$ of $10 \% \mathrm{BaCl} 2$ into the filtrate, then shaken and left for 30 minutes. Then added with $10 \mathrm{ml} \mathrm{NaNO} 210 \%$ solution then the solution is heated over a water bath at $1000 \mathrm{C}$ for 2 hours, and if a white precipitate appears, then the cyclamate content in the sample studied is positive (the sample contains cyclamate).

\section{Result and Discussion}

This research was conducted to analyze the cyclamate sweetener in bubble drinks traded around the city of Denpasar. The sample used was 30 samples, where the sample was collected randomly at each point of the city of Denpasar, namely North Denpasar, East Denpasar, South Denpasar, and West Denpasar. Samples of bubble drinks between branded and unbranded drinks were taken from North Denpasar, East Denpasar, South Denpasar, and West Denpasar with their respective codes, namely 20 samples of branded and 10 samples of non-branded ones. Then tested qualitatively from each sample found.

The results of the qualitative analysis show that all samples of branded bubble drinks circulating in the city of Denpasar do not contain artificial sweeteners (data are presented in Table 1 ). The results of this analysis compare with positive controls and negative controls. The positive control is indicated by positive samples containing artificial sweeteners, namely cyclamate. Based on Table 1, it can be seen that the results of the branded bubble drink from 20 samples showed that all samples did not contain cyclamate sweeteners as in the negative control.

The qualitative results of the unbranded bubble drink samples from 10 samples indicated that no cyclamate sweetener was detected (data are presented in Table 2). This is indicated by the absence of white precipitate on the same test as the negative control.

Based on the observation of Table 1, it is found that all branded bubble drinks circulating in the city of Denpasar do not contain cyclamate sweeteners. Synthetic/artificial sweeteners are additives that can cause sweetness in food but have no nutritional value (Yuliarti, 2007). In the beginning, synthetic sweeteners were produced for commercial purposes to meet the availability of food and beverage products for diabetes mellitus sufferers who had to control their food calories (Syah et al., 2005). Cyclamate consumption is only reserved for those who suffer from diabetes or people who are on a diet. People who are diabetic or are on a diet are not allowed to eat foods that contain lots of sugar 
levels (Marlina and Annisa, 2016). Excessive use of cyclamate can cause health problems. Toxicological studies conducted by Sparringa et al (2004), include the effects of acute toxicity, short-term toxicity, long-term/carcinogenicity, genotoxicity and reproductive toxicity.

Table 1. Results of Qualitative Analysis of Branded Bubble Beverage Samples

\begin{tabular}{|c|c|c|c|}
\hline $\begin{array}{l}\text { Sample } \\
\text { code }\end{array}$ & $\begin{array}{l}\text { Bubble } \\
\text { color }\end{array}$ & Color testing & Result \\
\hline $1 \mathrm{a}$ & Brown & $\begin{array}{l}\text { not formed white } \\
\text { precipitate }\end{array}$ & negative \\
\hline $2 b$ & Brown & $\begin{array}{l}\text { not formed white } \\
\text { precipitate }\end{array}$ & negative \\
\hline $3 c$ & Brown & $\begin{array}{l}\text { not formed white } \\
\text { precipitate }\end{array}$ & negative \\
\hline $4 d$ & Brown & $\begin{array}{l}\text { not formed white } \\
\text { precipitate }\end{array}$ & negative \\
\hline $5 e$ & Brown & $\begin{array}{l}\text { not formed white } \\
\text { precipitate }\end{array}$ & negative \\
\hline $6 f$ & Brown & $\begin{array}{l}\text { not formed white } \\
\text { precipitate }\end{array}$ & negative \\
\hline $7 g$ & Brown & $\begin{array}{l}\text { not formed white } \\
\text { precipitate }\end{array}$ & negative \\
\hline $8 \mathrm{~h}$ & Brown & $\begin{array}{l}\text { not formed white } \\
\text { precipitate }\end{array}$ & negative \\
\hline $9 \mathrm{i}$ & Brown & $\begin{array}{l}\text { not formed white } \\
\text { precipitate }\end{array}$ & negative \\
\hline $10 \mathrm{j}$ & Brown & $\begin{array}{l}\text { not formed white } \\
\text { precipitate }\end{array}$ & negative \\
\hline $11 a$ & Brown & $\begin{array}{l}\text { not formed white } \\
\text { precipitate }\end{array}$ & negative \\
\hline $12 b$ & Brown & $\begin{array}{l}\text { not formed white } \\
\text { precipitate }\end{array}$ & negative \\
\hline $13 c$ & Brown & $\begin{array}{l}\text { not formed white } \\
\text { precipitate }\end{array}$ & negative \\
\hline $14 \mathrm{~d}$ & Brown & $\begin{array}{l}\text { not formed white } \\
\text { precipitate }\end{array}$ & negative \\
\hline $15 \mathrm{e}$ & Brown & $\begin{array}{l}\text { not formed white } \\
\text { precipitate }\end{array}$ & negative \\
\hline $16 f$ & Brown & $\begin{array}{l}\text { not formed white } \\
\text { precipitate }\end{array}$ & negative \\
\hline $17 g$ & Brown & $\begin{array}{l}\text { not formed white } \\
\text { precipitate }\end{array}$ & negative \\
\hline $18 \mathrm{~h}$ & Brown & $\begin{array}{l}\text { not formed white } \\
\text { precipitate }\end{array}$ & negative \\
\hline $19 \mathrm{i}$ & Brown & $\begin{array}{l}\text { not formed white } \\
\text { precipitate }\end{array}$ & negative \\
\hline $20 \mathrm{j}$ & Brown & $\begin{array}{l}\text { not formed white } \\
\text { precipitate }\end{array}$ & negative \\
\hline $\begin{array}{c}\text { Negative } \\
\text { control }\end{array}$ & Brown & $\begin{array}{l}\text { not formed white } \\
\text { precipitate }\end{array}$ & negative \\
\hline $\begin{array}{l}\text { Positif } \\
\text { control }\end{array}$ & $\begin{array}{c}\text { Dark } \\
\text { Brown }\end{array}$ & $\begin{array}{l}\text { formed white } \\
\text { precipitate }\end{array}$ & positif \\
\hline $\begin{array}{r}\text { note: neg } \\
\text { pos }\end{array}$ & $=$ it & $\begin{array}{l}\text { 't contain cy } \\
\text { contain cycla }\end{array}$ & \\
\hline
\end{tabular}

The acute toxicity value of cyclamate which can endanger health expressed as LD-50 (lethal median dose) is $12,000 \mathrm{mg} / \mathrm{kg} \mathrm{BW}$. Cyclamate or cyclohexylsulfamic acid (C6H13NO3S) as an artificial sweetener is used in the form of calcium, potassium, and sodium cyclamate salts. In general, cyclamate salt is white crystalline, odorless, colorless, dissolves easily in water and ethanol and tastes sweet.

The use of cyclamate in food or drinks at low levels does not have an immediate effect on health. Based on Table 2, it can be seen that 10 samples of unbranded bubble drinks circulating in the city of Denpasar were not detected to contain cyclamate sweeteners. This is evidenced by the absence of a white precipitate in the sample test results as with the negative control. The principle of identifying the presence of cyclamate in the sample is using a deposition (Qamariah and Karmila, 2017).

Table 2. Results of Qualitative Analysis of Unbranded Bubble Beverage Samples

\begin{tabular}{|c|c|c|c|}
\hline $\begin{array}{c}\text { Sample } \\
\text { code }\end{array}$ & $\begin{array}{c}\text { Bubble } \\
\text { color }\end{array}$ & Color testing & Result \\
\hline $21 \mathrm{a}$ & Brown & $\begin{array}{l}\text { not formed white } \\
\text { precipitate }\end{array}$ & negative \\
\hline $22 b$ & Brown & $\begin{array}{l}\text { not formed white } \\
\text { precipitate }\end{array}$ & negative \\
\hline $23 c$ & Brown & $\begin{array}{l}\text { not formed white } \\
\text { precipitate }\end{array}$ & negative \\
\hline $24 d$ & Brown & $\begin{array}{l}\text { not formed white } \\
\text { precipitate }\end{array}$ & negative \\
\hline $25 \mathrm{e}$ & Brown & $\begin{array}{l}\text { not formed white } \\
\text { precipitate }\end{array}$ & negative \\
\hline $26 f$ & Brown & $\begin{array}{l}\text { not formed white } \\
\text { precipitate }\end{array}$ & negative \\
\hline $27 g$ & Brown & $\begin{array}{l}\text { not formed white } \\
\text { precipitate }\end{array}$ & negative \\
\hline $28 \mathrm{~h}$ & Brown & $\begin{array}{l}\text { not formed white } \\
\text { precipitate }\end{array}$ & negative \\
\hline $29 \mathrm{i}$ & Brown & $\begin{array}{l}\text { not formed white } \\
\text { precipitate }\end{array}$ & negative \\
\hline $30 \mathrm{j}$ & Brown & $\begin{array}{l}\text { not formed white } \\
\text { precipitate }\end{array}$ & negative \\
\hline $\begin{array}{c}\text { Negative } \\
\text { control }\end{array}$ & Brown & $\begin{array}{l}\text { not formed white } \\
\text { precipitate }\end{array}$ & negative \\
\hline $\begin{array}{l}\text { Positif } \\
\text { control }\end{array}$ & $\begin{array}{c}\text { Dark } \\
\text { Brown }\end{array}$ & $\begin{array}{l}\text { formed white } \\
\text { precipitate }\end{array}$ & positif \\
\hline
\end{tabular}

Precipitation is done by adding barium chloride in an acidic atmosphere then adding sodium nitrite so that a precipitate will form (Qamariah and Karmila, 2017). However, if you take cyclamate regularly for healthy people, there will likely be negative effects on your health. Excessive consumption will cause health problems such as asthma, headaches, memory loss, confusion, insomnia and brain cancer (Cahyadi, 2008). This is also confirmed by Hadiana (2018), regarding the effect of a person consuming artificial sweeteners, it is said that the 
effect on one's health if consuming artificial sweetener food additives does not directly affect the body, but the effects will accumulate in the next few years. Some artificial sweeteners such as saccharin, aspartame and cyclamate can cause children to become hyperactive, mentally retarded and in the long run at the risk of cancer. Also, the use of artificial sweeteners in excessive amounts is not recommended because it can cause detrimental effects on health, such as neurological diseases, insomnia, hypertension and brain cancer (Devitria \& Sepriyani, 2018).

The existence of regulations that the use of cyclamate is still allowed, and the ease of obtaining it at a relatively cheap price compared to natural sugar, has motivated food and beverage producers to use these artificial sweeteners in food or beverages. The price of cyclamate, which is much cheaper than sugar and the ease of obtaining it, has led to the rampant use of cyclamate among street food traders to get bigger profits. Traders generally use one of the Food Additives (BTP) which is easy to obtain, cheap, and can provide an attractive food appearance without finding out whether the BTP can be harmful to health (Ningtyas et al., 2012). Besides, according to Rasyid et al. (2011), cyclamate has a 30 times survival rate than sucrose. So that cyclamate is still an option in a strong sweet taste attractor to trade. The correct dose for adding artificial sweeteners is adjusted to the ADI (Acceptable Daily Intake). ADI is the maximum amount of a food additive in milligrams per kilogram of body weight that can be consumed each day for life without causing adverse health effects. The ADI for the artificial sweetener saccharin is 0-5 $\mathrm{mg} / \mathrm{kg}$ body weight. ADI for the artificial sweetener cyclamate is $0-11 \mathrm{mg} / \mathrm{kg}$ body weight (BPOM, 2014).

\section{Conclusion and Suggestion}

According to the results of research and observations made it can be concluded that 30 samples of branded bubble drinks and unbranded bubble drinks circulating in the city of Denpasar are safe from cyclamate sweetener content. It is recommended that in the future, do the test in another place, if the results are positive containing cyclamate, furthermore testing will be carried out, namely, the quantitative test.

\section{Acknowledgments}

We would like to thank the LPPM International Bali University and the Faculty of Health Sciences for supporting this research activity.

\section{References}

BPOM (2014). Peraturan Kepala Badan Pengawas Obat dan Makanan Republik Indonesia Nomor 4 Tahun 2014 tentang Batas Maksimum Penggunaan Bahan Tambahan Pangan Pemanis. Jakarta: BPOM, 1-63.

Cahyadi, W. (2008). Analisis dan Aspek Kesehatan Bahan Tambahan Pangan. Edisi Kedua, Jakarta: Penerbit Bumi Aksara, 317-361.

Devitria, R. \& Sepriyani, H. (2018). Identifikasi Natrium Siklamat pada Minuman Sirup yang dijual di Lima SD Kecamatan Sukajadi Pekanbaru. Jurnal Analis Kesehatan Klinikal Sain, 6,1-7.

Hadiana, A. B. (2018). Identifikasi Siklamat pda Pangan Jajanan Anak Sekolah dan Keluhan Kesehatan. Jurnal Kesehatan Lingkungan, 10(2),191-200.

Marlina, L., Annisa Rani Sa'adah. (2016). Identifikasi Kandungan Siklamat pada Minuman yang dijual di Pinggir Jalan Cihampelas Sampai Jalan Batujajar. TEDC,10(3),1-5.

Ningtyas, S.Y., Indarto, C., dan Probowati, B.D. (2012). Sikap Murid dan Penjual Makanan Jajanan tentang Higiene dan Sanitasi Makanan di Sekolah Dasar Negeri Kelurahan Rongtengah Kecamatan Sampang. AGROINTEK, 6(2),105-111.

Qamariah ,N., Karmila. (2017). Identifikasi Siklamat pada Kuah Dadar Gulung yang dijual di Kawasam Pelabuhan Rambang Kota Palangkaraya, Jurnal Surya Medika (JMS), 3(1), 37-53.

Ramadhani, N., Herlina, H., \& Utama, A. J. F. (2018). Penetapan Kadar Natrium Siklamat Pada Minuman Ringan Kemasan Dengan Menggunakan Metode Spektrofotometri UV. Jurnal Mandala Pharmacon Indonesia, 4(1), 7- 12 .

Ramadhani, N., Herlina, H., \& Utama, A. J. F. (2018). Penetapan Kadar Natrium Siklamat Pada Minuman Ringan Kemasan Dengan Menggunakan Metode Spektrofotometri UV. Jurnal Mandala Pharmacon Indonesia, 4(1), 7- 12 . 
Rasyid, R., Yohana, M. \& Mahyuddin, M. (2016). Analisis Pemanis Sintesis Natrium Sakarin dan Natrium Siklamat dalam Teh Kemasan. Jurnal Farmasi Higea, (3),52-57.

Sparringa RA, Kusumaningrum HD, Ra-hayu WP. (2004). Aplikasi Kajian RisikoBahan Tambahan Pangan. Jakarta: Badan POM.

Syah, Dahrul, Utama, Syatrya, Mahrus, Dan Zuhri. (2005). Manfaat dan Bahaya Bahan Tambahan Pangan. Bogor: Himpunan
Alumni Fakultas Teknologi Pertanian IPB. Syarifudin, L, U., Milaati, B., Riskawati, H., Arfa, K. (2017). Identifikasi Siklamat pada Jajanan Pasar di Pasar Hygienes Kelurahan Gamalama di Kota Ternate. JKL, 7(2), 90-96. Winarno, F.G. (2004). Kimia Pangan dan Gizi. PT. Jakarta: Gramedia Pustaka Utama.

Yuliarti, N. (2007). Awas Bahaya Dibalik Lezatnya Makanan. Yogyakarta:CV Andi Offset: 19-26. 